AGRICULTURE AND BIOLOGY JOURNAL OF NORTH AMERICA

ISSN Print: 2151-7517, ISSN Online: 2151-7525, doi:10.5251/abjna.2010.1.6.1133.1139

(C) 2010, ScienceHu $\beta$, http://www.scihub.org/ABJNA

\title{
Digestibility and growth in West African dwarf sheep fed gliricidia - based multinutrient block supplements
}

\author{
Aye P.A and M.K.Adegun \\ Animal Production and Health Sciences Dept. Univ. of Ado-Ekiti, Nigeria
}

\begin{abstract}
Sixty West African Dwarf (WAD) rams aged between $7-10$ months and mean Body Weight of $12.6 \mathrm{~kg}$ (range $9.3-14.5 \mathrm{~kg}$ ) were used to study the influence of Gliricidia - based multinutrient blocks (MNBs) as supplement to Panicum maximum and cassava peel feed for 12 weeks. Gliricidia + Poultry manure (GPMNB), Gliricidia + Urea + Poultry manure (GUPMNB) and Gliricidia + Urea (GUMNB) and Panicum - cassava peel (control) were analyzed for proximate composition, mineral content, gross energy and anti-nutritional factors. Mean weight gain of rams fed MNBs $(1.4 \pm 0.4-2.0 \pm 0.9 \mathrm{~kg})$ was significantly higher than those fed the control diet $(0.7 \pm 0.2 \mathrm{~kg})$. Rams fed control diet had the lowest feed conversion ratio $(50.6 \pm 0.2)$ while rams fed GUMNB, GPMNB and GUPMNB supplements had 20.6 $+0.1,21.3 \pm 1.2,26.6 \pm 0.4$. The dry matter intake of rams fed MNBs $\left(1573.33 \pm 2.1-1584.67 \pm 2.9\right.$ g day $\left.^{-1}\right)$ was significantly $(P<0.05)$ higher than $\left(1102.00 \pm 9.6 \mathrm{~g} \mathrm{day}^{-1}\right)$ in the control diets . Daily average gain of $28.6 \pm 0.0,47.6 \pm 1.6$, $57.1 \pm 0.0 \mathrm{~g}$ for GUPMNB, GPMNB and GUMNB respectively were higher than in the control diet $(9.5 \pm 4.2 \mathrm{~g})$. Nitrogen balance values for sheep on treatments GUMNB , GUPNMB and GPMNB were significantly $(P<0.05)$ higher than in the control diet. The coefficient digestibility of DM , CP , CF , EE , NFE of the rams in the control ration were consistently lower $(P<0.05)$ than those fed the MNBs supplemented ration. The body length gains of rams fed MNBs $(15.75 \pm 3.5 \mathrm{~cm}-25.0 \pm$ $0.7 \mathrm{~cm})$ were significantly $(P<0.05)$ higher than those rams fed the control diet $(9.6 \pm 1.2 \mathrm{~cm})$. It was concluded that Gliricidia - based multinutrient block supplements could be fed with Panicum cassava peels to improve feed intake, nutrient digestibility and nitrogen utilization leading to a better performance of sheep.
\end{abstract}

Keywords: Panicum - cassava peels, Gliricidia-based multinutrient blocks, utilization, performance, conversion ratio.

\section{INTRODUCTION}

Small ruminants suffer from scarcity in feed supply and pasture quality in the humid region of West Africa, especially during the dry season when the natural vegetation is of poor nutritive value (Akinfala and Tewe,2002; Aye, 2007). There has been a search for and interest in the use of unconventional and less expensive feed ingredients to mitigate this scarcity(Odeyinka et al.2003). Low Nitrogen (N) forages and cassava peel-based diets supplemented with urea show increased feed intake and protein digestibility in ruminants but use of browse plants and other feed sources alone or as supplement have proved satisfactory. Browse plants with high nutritive values have been successfully fed to small ruminants in alley faming systems (Ngwa and Tawah, 2002; Fasae and Alokan, 2006). Gliricidia sepium is a suitable feed for ruminant which it can consume in large quantities without deleterious effects on animal performance(Oladokun et al., 2003; Bawala et al.,2006). Multinutrient blocks are lick blocks containing urea, molasses, vitamins, minerals and other nutrients(Hendratno, 1991). Multinutrient blocks represent a vast reservoir of cheap nutrients, particularly for ruminants(Hendratno et al., 1989). Multinutrient feed block has been advocated as a panacea to protein and energy deficiencies in ruminants especially during the extended dry season (Onwuka, 1999). It has been demonstrated to improve dry matter intake and live weight gain in lambs on a basal diet of wheat straw(Hendratno et al.,1991).

The objective of this study therefore, was to evaluate the effects of Poultry manure and Urea as sources of nutrients in a multinutrient block used to supplement Panicum- Cassava peel diet.

\section{MATERIALS AND METHODS}

Experimental site: The study was conducted in the Small Ruminants Section of the Teaching and 
Research Farm, University of Ado-Ekiti, Nigeria.

Experimental animals and management: Sixty (60) West African Dwarf (WAD) sheep aged 7-10months with a mean body weight of $12.6 \mathrm{~kg}$ (range $9.3-14.5$ $\mathrm{kg}$ ) were purchased from the open market at OtunEkiti. On arrival, the sheep were given antistress and prophylactic treatments consisting of intramuscular injection of Oxytetracycline (LA:1ml/10kgBW) and a coccidiostat. They were dewormed with Baminth $11^{\mathrm{R}}$ wormer $(12.5 \mathrm{~g} / \mathrm{kgBW})$ and bathed with Asuntol ${ }^{R}$ powder solution (3g/litre) to eliminate ectoparasites. They were also given Tissue Culture Rinderpest Vaccine (TCRV) against PPR about a week after arrival. The animals were quarantined for a period of 4 weeks, and subsequent housed individually in an open- sided, well-ventilated pens. The sheep were allowed fourteen days adaptation period during which they were fed with multinutrient blocks, as well as Panicum maximum and cassava peels. The animals had free access to fresh water daily.

\section{Experimental diet (multi-nutrient blocks)} preparation. Gliricidia - molasses - urea blocks, Gliricidia - molasses - poultry manure blocks and Gliricidia - molasses - urea - poultry manure blocks were made as follows:

Cement was mixed(W/W) with water at the ratio of 1:2 , Gliricidia residue, molasses, urea/poultry manure, $\mathrm{NaCl}$ were added in that order and the cement mixture added last. The mixture was poured into a cellophane-lined plastic mould measuring $14 \mathrm{~cm} \times 10 \mathrm{~cm} \times 5 \mathrm{~cm}$. The blocks formed were put on table tops, sun-dried and packed into jute bags.

Guinea grass( Panicum maximum) was harvested at the pre-anthesis stage at a height of about $20 \mathrm{~cm}$. The harvested grass was chopped into small bits (about $2-3 \mathrm{~cm}$ ) allowed to wilt for $2-3$ days (for each cutting), baled into jute bags and kept in a wellventilated room. The total collection lasted about 12 weeks.

Cassava peels were collected fresh from a Gari processing factory in Ado-Ekiti and sun dried for 5 days after which it was packed into jute bags and kept in well-ventilated room. The ingredient composition (\%) of the Gliricidia - based multinutrient blocks are as presented in Table 1.

Feeding of Animals: Feeding which lasted for 12 weeks was preceded by 2 weeks of acclimatization. The animals were weighed before the commencement of the feeding. They were divided into four groups of fifteen animals balanced for body weight and randomly allocated to dietary treatments. The experimental diets were fed in two installments per day at $0800 \mathrm{~h}$ and $1600 \mathrm{~h}$ respectively.

The multinutrient blocks were fed to a basal diet of Panicum maximum plus cassava peels based on daily feed allowance of $5.0 \%$ of BW and fresh water was supplied regularly in the pens.

Table 1: Ingredient composition (\%) of the experimental multinutrient blocks

\begin{tabular}{|l|l|l|l|}
\hline Ingredients & Treatment & \multicolumn{2}{l|}{} \\
\hline & GPMNB & GUPMNB & GUMNB \\
\hline Molasses & 40 & 40 & 40 \\
\hline Urea & - & 5 & 10 \\
\hline $\begin{array}{l}\text { Poultry } \\
\text { manure }\end{array}$ & 10 & 5 & - \\
\hline NaCl & 5 & 5 & 5 \\
\hline Cement & 15 & 15 & 15 \\
\hline $\begin{array}{l}\text { Gliricidia } \\
\text { residue }\end{array}$ & 30 & 30 & 30 \\
\hline Total & 100 & 100 & 100 \\
\hline
\end{tabular}

GPMNB =Gliricidia - Poultry manure multinutrient blocks

GUPMNB = Gliricidia - Urea - Poultry manure multinutrient blocks GUMNB =Gliricidia - Urea multinutrient blocks

Digestibility and Nitrogen balance trials: The animals were transferred into wooden metabolic cages fitted with facilities for separate collection of feaces and urine. The quantity of feed offered, feed refusal, feaces and urine were determined for 7 days, after 14 days of adjustment to the cages. Ten percent of the feaces and urine collected daily over the 7- day period were bulked. Nitrogen loss from urine and bacteria growth infestation were prevented by introducing $20 \mathrm{~cm}^{3}$ of $10 \% \mathrm{H}_{2} \mathrm{SO}_{4}$ into a well-labelled urine collection bottle and stored in a refrigerator. The ten percent feaces taken were weighed and used for moisture determination. The remaining feaces were oven dried at $70^{\circ} \mathrm{C}$ for 36 hours, milled and stored in air tight bottles.

Data collection: The daily feed provided and the left over of the previous day's feed were weighed to determine the total feed intake of each animal and on daily basis.

Samples of experimental diets were collected during the experiment for dry matter (DM) determination and proximate analysis. The samples were weighed and dried in an oven at $105^{\circ} \mathrm{C}$ to constant weight. The dried samples were weighed and ground to pass 
through a $2 \mathrm{~mm}$ sieve. The milled samples were subjected to proximate analysis as described by AOAC (1995). The animals weight were taken once a week before the morning feed was offered. Linear body measurements including body length, height at withers and heart girth were also recorded once a week.

Chemical analysis: The milled experimental diets and feacal samples were analyzed for dry matter (DM) Crude protein (CP) Crude fibre (CF) Ether extract (EE) and Nitrogen free extract (NFE) according to AOAC (1995). Gross energy of feeds was determined with adiabatic bomb calorimeter. Mineral analysis was by wet digestion of samples in $\mathrm{HNO}_{3} / \mathrm{HClO}_{4}$ and $\mathrm{Ca}$ and $\mathrm{P}$ determined with atomic absorption spectrophotometer.

The Nitrogen content of the urine was determined by the Kjeldahl method according to AOAC (1990) procedure.

Analyses of extractable condensed tannins was carried out by the method described in Markkar et al (1993).

Statistical Analysis: Data generated from parameters investigated were subjected to Analysis of Variance (ANOVA) using the General Linear Modelling Procedure (SAS 1988). Significant differences between treatment means were separated using Duncan's Multiple Range Test.

\section{RESULTS}

The proximate composition, energy, mineral and antinutrients contents of Gliricidia - based multinutrient blocks are shown in Tables 2, 3 and 4.

Table 2: Proximate composition ( $\mathrm{g} \mathrm{Kg}^{-1}$ ) and Gross energy $\left(\mathrm{MJ} \mathrm{Kg}^{-1}\right.$ ) of the experimental Multinutrient blocks

\begin{tabular}{|l|l|l|l|l|l|l|l|}
\hline Treatments & DM & CP & CF & EE & Ash & NFE & $\begin{array}{l}\text { Gross } \\
\text { Energy }\end{array}$ \\
\hline GPMNB & $785.6 \pm 0.01$ & $179.0 \pm 1.20$ & $70.3 \pm 0.01$ & $81.9 \pm 0.01$ & $333.1 \pm 0.04$ & $484.5 \pm 0.57$ & 11.67 \\
\hline GUPMNB & $711.8 \pm 0.01$ & $261.2 \pm 0.61$ & $121.0 \pm 0.03$ & $91.1 \pm 0.15$ & $284.9 \pm 0.05$ & $324.0 \pm 0.98$ & 14.56 \\
\hline GUMNB & $765.6 \pm 0.02$ & $344.2 \pm 1.19$ & $77.4 \pm 0.04$ & $65.1 \pm 0.01$ & $266.0 \pm 0.04$ & $247.2 \pm 1.16$ & 15.48 \\
\hline CV & 5.06 & 85.15 & 30.65 & 15.61 & 11.74 & 34.41 & 14.30 \\
\hline
\end{tabular}

$\mathrm{CV}=$ Coefficient of Variation

Table 3: Mineral constituents of the experimental multinutrient blocks ( $\mathrm{mg} \mathrm{kg}^{-1}$ )

\begin{tabular}{|l|l|l|l|l|l|l|l|l|l|l|}
\hline Treatment & $\mathrm{Na}$ & $\mathrm{P}$ & $\mathrm{K}$ & $\mathrm{Ca}$ & $\mathrm{Mg}$ & $\mathrm{S}$ & $\mathrm{Zn}$ & $\mathrm{Fe}$ & $\mathrm{Cu}$ & $\mathrm{Mn}$ \\
\hline GPMNB & 873.50 & 162.50 & 923.20 & 766.60 & 166.70 & 141.67 & 258.30 & 158.30 & 0.08 & 50.00 \\
\hline GUPMNB & 771.40 & 71.40 & 831.00 & 892.90 & 142.90 & 131.55 & 414.30 & 264.30 & $\mathrm{ND}$ & 57.00 \\
\hline GUMNB & 642.10 & 89.40 & 663.50 & 757.10 & 192.90 & 121.43 & 171.40 & 257.10 & $\mathrm{ND}$ & 57.00 \\
\hline CV & 15.71 & 44.77 & 16.34 & 9.41 & 14.93 & 7.69 & 43.74 & 26.14 & 96.00 & 11.00 \\
\hline
\end{tabular}

ND $=$ Not Detected

Table 4: Antinutrients in the experimental multinutrient blocks

\begin{tabular}{|l|c|c|l|c|}
\hline Treatments & $\begin{array}{l}\text { Tannin } \\
\left(\mathrm{g}^{100 \mathrm{~g}^{-1}}\right)\end{array}$ & $\begin{array}{l}\text { Phytin }-\mathrm{P} \\
\left(\mathrm{mg} \mathrm{100g}^{-1}\right)\end{array}$ & $\begin{array}{l}\text { Phytate } \\
\left(\mathrm{mg} \mathrm{100g}^{-1}\right)\end{array}$ & $\begin{array}{l}\text { Oxalate } \\
\left(\mathrm{mg} \mathrm{100g}^{-1}\right)\end{array}$ \\
\hline GPMNB & 0.44 & 6.26 & 22.24 & 7.56 \\
\hline GUPMNB & 1.54 & 3.94 & 14.00 & 7.83 \\
\hline GUMNB & 0.63 & 2.55 & 9.06 & 8.73 \\
\hline CV & 67.58 & 44.10 & 44.10 & 7.62 \\
\hline
\end{tabular}

Gliricidia - Poultry manure multinutrient Blocks (GPMNB) with the highest dry matter $(785.6 \pm 0.01 \mathrm{~g}$ $\left.\mathrm{kg}^{-1}\right)$ has the least crude protein $\left(179.0 \pm 1.20 \mathrm{~g} \mathrm{~kg}^{-1}\right)$, crude fibre $\left(70.3 \pm 0.03 \mathrm{~g} \mathrm{~kg} \mathrm{~kg}^{-1}\right.$ and gross energy $\left(11.67 \mathrm{MJ} \mathrm{kg}^{-1}\right)$. Gliricidia - urea multinutrient blocks (GUMNB) has the highest crude protein $\left(344.2 \pm 1.19 \mathrm{~g} \mathrm{~kg}^{-1}\right)$ and gross energy (15.48MJ $\mathrm{kg}^{-1}$ ) while Gliricidia - urea - Poultry manure multinutrient blocks (GUPMNB) had least dry matter(711.8 $\left.\pm 0.01 \mathrm{~g} \mathrm{~kg}^{-1}\right)$ but the best crude 
fibre $\left(121.0 \pm 0.03 \mathrm{~g} \mathrm{~kg}^{-1}\right)$ and ether extract $(91.1 \pm 0.15 \mathrm{~g}$ $\mathrm{kg}^{-1}$ ).

The nitrogen free extractive value was highest in GPMNB (484.5 $\left.\pm 0.57 \mathrm{~g} \mathrm{~kg}^{-1}\right)$ and least value was in GUMNB(247.2 $\left.\pm 1.16 \mathrm{~g} \mathrm{~kg}^{-1}\right)$.

$\mathrm{Na}, \mathrm{Ca}, \mathrm{K}, \mathrm{Mg}, \mathrm{Zn}$ and $\mathrm{Fe}$ were the most abundant minerals in the multinutrient blocks and the values were $\quad \mathrm{Na}\left(642.10-873.50 \mathrm{mgKg}^{-1}\right), \quad \mathrm{Ca}(757.10-$ 892.90mg Kg $\left.{ }^{-1}\right), \quad \quad \mathrm{P}\left(663.50-923.20 \mathrm{mg} \mathrm{Kg}^{-1}\right)$, $\mathrm{Mg}\left(142.90-192.90 \mathrm{mgKg}^{-1}\right), \quad \mathrm{Zn}\left(171.40-414.30 \mathrm{mgKg}^{-}\right.$ $\left.{ }^{1}\right), \mathrm{Fe}\left(158.30-264.30 \mathrm{mg} \mathrm{Kg}^{-1}\right)$ while $\mathrm{Cu}$ was the least abundant $\left(0.08 \mathrm{mgKg}^{-1}\right)$. GPMNB contained the highest amount of $\mathrm{Na}, \mathrm{P}, \mathrm{K}, \mathrm{S}$ and $\mathrm{Cu}$ while $\mathrm{Ca}, \mathrm{Fe}$ and $\mathrm{Zn}$ were highest in GUPMNB and $\mathrm{Mg}$ and $\mathrm{Mn}$ in
GUMNB.

The tannins ranged from $0.44 \mathrm{~g} 100 \mathrm{~g}^{-1} \mathrm{DM}$ in GPMNB

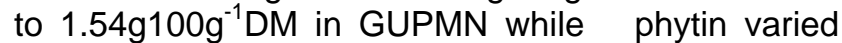

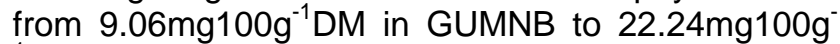
${ }^{1} \mathrm{DM}$ in GPMNB. The Phytin-P ranged from $2.55 \mathrm{mg} 100 \mathrm{~g}^{-1} \mathrm{DM}$ in GUMNB to $6.26 \mathrm{mg} 100 \mathrm{~g}^{-1} \mathrm{DM}$ in GPMNB and oxalate content varied from

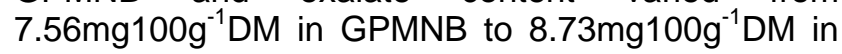
GUMNB.

Weight gain, feed consumption and feed efficiency and body measurements as affected by the diets are shown in Tables 5, 6 and 7.

Table 5: Performance of sheep fed basal diet supplemented with Gliricidia - based multinutrient blocks

\begin{tabular}{|c|c|c|c|c|}
\hline \multirow[t]{2}{*}{ Parameters } & \multicolumn{4}{|l|}{ Treatments } \\
\hline & GPMNB & GUPMNB & GUMNB & CONTROL \\
\hline DM1 (g day $\left.{ }^{-1}\right)$ & $1584.67+2.9^{a}$ & $1528.00+5.3^{\mathrm{a}}$ & $1573.33+2.1^{a}$ & $1102.0+9.6^{b}$ \\
\hline DM1 (g day $\left.{ }^{-0.75}\right)$ & $250.64+3.4 a$ & $244.38+3.4^{\mathrm{a}}$ & $249.81+2.6^{a}$ & $191.17+1.3^{b}$ \\
\hline Weight gain $(\mathrm{kg})$ & $1.9+0.2^{\mathrm{a}}$ & $1.4+0.4^{b}$ & $2.0+0.9^{\mathrm{a}}$ & $0.7+0.2^{c}$ \\
\hline $\mathrm{W}^{0.75}$ gain $(\mathrm{kg})$ & $0.9+0.3^{\mathrm{a}}$ & $0.6+0.4^{b}$ & $0.9+0.4^{a}$ & $0.4+0.2^{c}$ \\
\hline $\begin{array}{l}\text { Feed Conversion } \\
\text { Ratio }\end{array}$ & $21.3+1.2^{\mathrm{a}}$ & $26.6+0.4^{b}$ & $20.6+0.1^{a}$ & $50.6+0.2^{c}$ \\
\hline
\end{tabular}

$a, b, c$, values with differing superscripts in the same row differ significantly $(P<0.05)$

The mean weight gain (WG), heart girth gain (HGG), Height at wither gain (HWG), Body length gain (BLG) and feed conversion ratio (FCR) were significantly
$(P<0.05)$ influenced by the dietary treatments. The weight gain of sheep fed GPMNB, GUPMNB and GUMNB were significantly $(P<0.05)$ higher than those fed the control diet but GUMNB produced the highest weight gain.

Table 6: Morphostructural differentiation of Sheep fed experimental multinutrient blocks (cm)

\begin{tabular}{|l|c|c|c|}
\hline \multirow{2}{*}{ Treatment } & \multicolumn{2}{|c|}{ Parameters } & Body Length gain \\
\cline { 2 - 4 } & Heart girth gain & Height at Wither gain & $20.3+2.0^{\mathrm{a}}$ \\
\hline GPMNB & $16.0+0.9^{\mathrm{c}}$ & $20.4+1.0^{\mathrm{b}}$ & $15.7+3.5^{\mathrm{b}}$ \\
\hline GUPMNB & $18.0+0.3^{\mathrm{b}}$ & $23.0+0.3^{\mathrm{a}}$ & $25.0+0.7^{\mathrm{a}}$ \\
\hline GUMNB & $22.3+0.3^{\mathrm{a}}$ & $21.7+0.6^{\mathrm{b}}$ & $9.6+1.2^{\mathrm{c}}$ \\
\hline Control & $8.7+0.6^{\mathrm{d}}$ & $6.3+0.7^{\mathrm{c}}$ & ${ }^{\mathrm{b}}$ \\
\hline
\end{tabular}

a, b, c, d values with differing superscripts in the same row differ significantly $(\mathrm{P}<0.05)$

Sheep fed control diet had the least feed conversion ratio $(50.6 \pm 0.2)$ while sheep fed supplemental GUMNB had highest feed conversion ratio $(20.6 \pm 0.1)$ followed by GPMNB $(21.3 \pm 1.2)$ and GUPMNB (26.60.4).
The body length gain of sheep fed GUMNB $(25.0 \pm 0.7 \mathrm{~cm})$, GPMNB $(20.3 \pm 2.09 \mathrm{~cm})$ and GUPMNB $(15.7 \pm 3.5 \mathrm{~cm})$ were significantly $(P<0.05)$ higher than those fed the control diet $(9.6 \pm 1.2 \mathrm{~cm})$. A similar trend was observed for heart girth gain (HGG) and height at wither gain which were significantly $(P<0.05)$ higher in sheep fed diets supplemented with Gliricidia - based multinutrient blocks. 
The dry matter intake (DM1) were higher in sheep fed diets supplemented with Gliricidia - based multinutrient blocks. The values ranged from $1528.00+5.3 \mathrm{~g} \mathrm{day}^{-1}$ in GUPMNB to $1584.67+2.9$ gday $^{-}$

${ }^{1}$ in GPMNB which differed significantly $(\mathrm{P}<0.05)$ from the value of $1102.00 \pm 9.6$ gday $^{-1}$ in the control diets. The metabolic DM1 also followed the same trend as the dry matter intake being consistently high with supplementation of the multinutrient blocks. GUMNB, GUPMNB and GUPMNB supplementation diets produced daily average weight gain of $57.1 \pm 0.0$, $47.6+1.6$ and $28.6+0.8 \mathrm{~g}$ respectively which were significantly superior $(P<0.05)$ to the $9.5 \pm 4.9 \mathrm{~g}$ in the control treatment.

Table 7: Live weight change of Sheep fed basal diet supplemented with Gliricidia - based multinutrient blocks

\begin{tabular}{|c|c|c|c|c|}
\hline \multirow[t]{2}{*}{ Parameters } & \multicolumn{2}{|c|}{ Treatment } & & \\
\hline & GUPMNB & GPMNB & GUMNB & CONTROL \\
\hline Initial Live Weight (Kg) & $11.9+2.4$ & $12.0+2.7$ & $12.0+0.8$ & $11.8+1.2$ \\
\hline Final Live Weight (Kg) & $12.1+2.4$ & $12.3+0.2$ & $12.4+0.8$ & $11.9+1.2$ \\
\hline Mean Live Wt gain (Kg) & $0.2+0.0^{b}$ & $0.3+0.1^{a}$ & $0.4+0.0^{\mathrm{a}}$ & $0.1+0.1^{\mathrm{c}}$ \\
\hline Average Daily Wt gain (g) & $28.6+0.0^{c}$ & $47.6+1.6^{b}$ & $57.1+0.0^{\mathrm{a}}$ & $9.5+4.9^{d}$ \\
\hline Metabolic Daily Wt gain $\left(\mathrm{g}^{0.15}\right)$ & $12.4+0.0^{b}$ & $18.1+1.4^{\mathrm{a}}$ & $20.8+0.0^{\mathrm{a}}$ & $5.4+2.9^{c}$ \\
\hline
\end{tabular}

$\mathrm{a}, \mathrm{b}, \mathrm{c}, \mathrm{d}$ values with differing superscripts in the same row differ significantly $(\mathrm{P}<0.05)$

Table 8: Nitrogen Utilization by Sheep fed experimental multinutrient blocks ( $\mathrm{g} \mathrm{day}^{-1}$ )

\begin{tabular}{|c|c|c|c|c|}
\hline \multirow[t]{2}{*}{ Parameters } & \multicolumn{4}{|l|}{ Treatment } \\
\hline & GUPMNB & GPMNB & GUMNB & CONTROL \\
\hline Nitrogen Intake & $5.30 \pm 0.5^{b}$ & $6.28 \pm 0.6^{a}$ & $8.92 \pm 0.5^{a}$ & $4.25 \pm 0.3^{c}$ \\
\hline Faecal - N & $2.98 \pm 0.2$ & $2.78 \pm 0.3$ & $2.88 \pm 0.2$ & $2.71 \pm 0.1$ \\
\hline Digested - N & $2.32 \pm 0.2^{b}$ & $3.50 \pm 0.2^{b}$ & $6.04 \pm 0.1^{a}$ & $1.51 \pm 0.2^{C}$ \\
\hline Urinary - N & $0.56 \pm 0.1^{\mathrm{c}}$ & $0.70 \pm 0.1^{\mathrm{a}}$ & $0.64+0.1^{b}$ & $0.40 \pm 0.0^{\mathrm{d}}$ \\
\hline$N-$ Retention & $33.33+2.3^{c}$ & $44.51+4.8^{b}$ & $59.83+2.7^{\mathrm{a}}$ & $26.18+3.6^{\mathrm{d}}$ \\
\hline
\end{tabular}

$a, b, c, d$ values with differing superscripts in the same row differ significantly $(P<0.05)$

The nitrogen metabolism data shown in Table 8 indicate that variations in digested nitrogen $\left(g\right.$ day- $\left.^{1}\right)$ were significant $(P<0.05)$. The sheep on GUMNB digested significantly higher $(P<0.05)$ values of $N$ per day than those on GUPMNB and GPMNB which were significantly superior $(P<0.05)$ to those on the control diets.

The treatment effects on nitrogen balance(NB) were significant $(P<0.05)$. NB values for sheep on

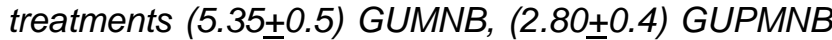
and (1.77+0.3) GPMNB were significantly higher $(P<0.05)$ than the mean values for sheep on control (1.12+0.2) suggesting that the higher $N$-intake significantly $(P<0.05)$ improved $N$-balance.

The N-retention (NR) in treatments GUMNB,
GUPMNB and GPMNB were 59.83+2.7, 44.51+4.8 and $33.33+2.3 \mathrm{~g} \mathrm{day},^{-1}$ respectively which were significantly higher $(P<0.05)$ than in the control treatment $\left(26.18+3.6\right.$ gday $\left.^{-1}\right)$. N-retention for diets with high protein levels tends to be higher $(P<0.05)$ compared to low protein level diets.

The coefficients of digestibility of dry matter, crude protein, crude fibre, ether-extract, ash and nitrogen free extracts of the animals fed on the control diets were consistently lower than those fed the Gliricidiabased multinutrient blocks supplemented rations. A similar result was obtained on percent digestible crude protein, crude fibre, ether extract, ash and NFE. 
Agric. Biol. J. N. Am., 2010, 1(6): 1133-1139

Table 9: Nutrient digestibility coefficient of Sheep fed basal diet supplemented with Gliricidia - based multinutrient blocks.

\begin{tabular}{|c|c|c|c|c|}
\hline \multirow[t]{2}{*}{ Nutrients } & \multicolumn{4}{|l|}{ Treatments } \\
\hline & GUPMNB & GPMNB & GUMNB & CONTROL \\
\hline Dry matter & $85.94+1.6^{\mathrm{a}}$ & $86.79+1.3^{\mathrm{a}}$ & $85.24+2.0^{\mathrm{a}}$ & $68.66+2.6^{b}$ \\
\hline Crude protein & $80.74+3.0^{b}$ & $85.41+1.9^{a}$ & $85.34+1.6^{\mathrm{a}}$ & $64.54+0.5^{c}$ \\
\hline Crude fibre & $93.06 \pm 2.4^{\mathrm{a}}$ & $93.80 \pm 0.5^{a}$ & $92.13 \pm 1.1^{\mathrm{a}}$ & $76.45 \pm 5.6^{b}$ \\
\hline Ether extract & $76.33+4.4^{\mathrm{a}}$ & $75.09 \pm 3.2^{\mathrm{a}}$ & $71.79 \pm 4.4^{b}$ & $61.68 \pm 2.9^{C}$ \\
\hline Nitrogen free extracts & $93.64+0.5^{a}$ & $92.85+15^{a}$ & $91.70+0.9^{a}$ & $71.98+1.9^{b}$ \\
\hline
\end{tabular}

$a, b, c, d$ values with differing superscripts in the same row differ significantly $(P<0.05)$

\section{DISCUSSION}

The proximate compositions, energy, mineral and anti-nutritional constituents of the multinutrient blocks revealed their potentials as sources of feed for ruminants. The dry matter content of the blocks was quite high and appear adequate, especially they are to serve as supplements to other conventional feeding stuffs with urea and poultry manure known for ammonia release. The nitrogen free extractives reflect the energy content of the blocks and these are in relation to the molasses content. Thus, multinutrient blocks will supply reasonable levels of available energy and nitrogen when fed to animals. The crude protein content of GPMNB, GUMNB and GUMNB compared favourably with and even surpassed those reported for urea-molasses blocks(Mata and Cambellas, 1992; Onwuka, 1999). The study also shows that the Gliricidia-based multinutrient blocks contained some valuable mineral elements-K, $\mathrm{Na}, \mathrm{Ca}, \mathrm{Mg}, \mathrm{P}$ and $\mathrm{Zn}$ at levels considered particularly high when compared with most other foods (Leng et al, 1991), while Fe which is commonly deficient in many diets is fairly abundant. The anti-nutrients content were very low compared with most other foods(Agbede and Aletor, 2004; Agbede, 2006; Aye 2007).

This study demonstrates that sheep fed Gliricidia based multinutrient blocks performed better than those fed control diet of Panicum + cassava peels only. This suggests that the multinutrient blocks have the tendency of improving rumen fermentation which provides a better balance of nutrients to the animals for absorption (Habib et al., 1991), and so can be used as a farm package to increase growth rates of sheep under confinement sheep management.

Previous studies have shown that multinutrient blocks improved heart girths, height at wither and body length of sheep dependent on low quality forages as their main diet (Habib et al., 1991; Hendratno et al., 1991; Hadjipamayiotou et al., 1993b). Increase in biometric measurements brings about progressive increase in feed intake as well as effective utilization of the multinutrient blocks. This finding confirms the experiences in other countries where multinutrient blocks manufactured from urea and/or poultry manure and agro-industrial by-products are used as supplements for improving the productivity of sheep (Sancoucy et al., 1988; Leng et al., 1991; Hadjipanayioutou et al., 1993a). Therefore urea and or poultry manure or urea + poultry manure combination of $10 \%$ in block packages further confirmed that urea used at this level will not have adverse effect on the block utilization by animals(Habib et al 1991).

\section{CONCLUSION}

Multinutrient blocks are potential sources of readily available energy and nitrogen which would fill the gap in feed availability to ruminants during the extended annual dry season months of November through April. The ease of preparation and maintenance make the block technologies easy for adoption by small-scale farmers at rural level.

Rations supplements with multinutrient blocks offered a balance of essential nutrients, which is the major determinant of dry matter intake and growth rate and so would overcome dry season weight losses and rather poor performance in sheep fed cut and carry fodder.

\section{REFERENCES}

Agbede, J.O and Aletor V.A. (2004). Chemical characterization and protein quality evaluation of leaf protein concentrate from Gliricidia sepium and Leucaena leucocephala. J. Food Sci. Technol 39: 253 $-261$.

Agbede, J.O. (2006). Characterization of leaf meals, 
protein concentration and residues from some tropical Leguminous plants. J. Sci. Food Agric. 86: 22 - 82.

Akinfala, E.O and Tewe O.O (2002). Utilization of varying levels of palm kernel cake and cassava peels by growing pig. Trop. Anim. Prod. Invest 5: 87 - 93.

AOAC (1995). Official Methods of Analysis. $16^{\text {th }}$ edn. (Association of official Analytical Chemists Washington, Dc.

AOAC (1990). Official Methods of Analysis (Association of official Analytical Chemists, Inc. Virginia, USA.

Aye, P.A (2007). Production of multinutrient blocks for Ruminants and Alcohol from the waste products of Leucaena leucocephala and Gliricidia sepium leaves using local Technologies. Ph.D Thesis. Federal University of Technology, Akure.

Bawala, T.O; Akinsoyinu, A.O and Folorunso O.R (2006). Nutritional evaluation of varying proportion of Gliricidia sepium and Ficus thonningii leaves in the diet of young West African Dwarf goats. Nig. J.Anim. Prod. 33(1): $112-117$

Fasae, O.A and Alokan J.A (2006). Growth performance of weaner Yankasa sheep fed varying levels of Leucaena leucocephala leaf residues. Asses series A 6(2): 323 $-328$.

Habib, W; Basit Ali Shah, S; Wahidullah, W and Ghuftranullah (1991). The importance of urea molasses blocks and by-pass protein in animal production: the situation in Pakistan. In: Isotope and Related Technique in Animal Production and Health by International Atomic Energy. Vienna. 133-145.

Hadjipanayiotou, M; Verhaegbe, L; Allen, M; Kronfoleh, A.R; Labban, L.M; Shurbaji, A; Al-Wadi, M; Dassouki, M; Shaker B and Am in M (1993a) Urea Blocks: 1: Methodology of block making and different formulae tested in Syria. Livestock Research for Rural Development 5(3):22-32

Hadjipanayiotou, M; Verhaeghe, Li, Kronfoleh, A.R; Labban, L.M; Amin, M; Al-Wadi, M; Badran, A; Dawa, K; Shubaji, A; Houssein, M; Malki, G; Naigin, T; Merawi, A.R and Harres, A.K (1993b) Urea Blocks. II. Performance of cattle and sheep offered urea blocks in Syria. Lwestock Research for Rural Development 5(3):42-53

Hendratno, C; Tjiptosumirat, T and Sofian L.A (1989). Effective use of molasses blocks as supplements for
Etawah cross-bred goats. Proc. Conf. on Ruminants and Small Ruminants. Research Inst. for Animal Production, Bogor 169.

Hendratno, C; Nolan, J.V and Leng, R.A. (1991). The importance of urea-molasses multinutrient blocks for ruminant production in Indonesia. In: Isotape and Related Techniques in Animal Production and Health by International Atomic Energy Agency. Vienna. 157169.

Leng, R.A; Preston, T.R; Sansoucy, R and George Kunju, P.L (1991). Multinutrient blocks as a strategic supplement for ruminants. World Animal Review 67: $11-19$

Mata, D and Cambellas J. (1992). Infleunce of multinutrient blocks on intake and rumen fermentation of dry cows fed basal diets of Trachypogon $s p$ and Cynodon plectostachyus hays. Livestock Research for Rural Development 4 No 2

Ngwa, A.T and Tawah, C.I (2002). Effect of supplementation with leguminous crop residues or concentrates on the voluntary intake and performance of Kirdi sheep. Tropical Anim. Hlth Prod. 34 (1): 65 73.

Odeyinka, S.M; Hector, B.L and Orskov, E.R (2003). Evaluation of the nutritive value of the browse species: Gliricidia sepium (Jacq). Walp, Leucaena leucocephala (Lam) de. Wit and Cajanus cajan (L) Millsp from Nigeria. Journal of Animal and Feed Science, 12: 341 -349 .

Oladotun, O.A; Aina, A.B.J. and Oguntona, E.B (2003). Evaluation of formulated agro-industrial wastes as dry season feed for sheep. Nig. J.Anim. Prod. 30 (1): $71-$ 80.

Onwuka, C.F.I (1999). Molasses blocks as supplementary feed resources for ruminants. Arch. Zootech 48: $89-$ 94.

Sansoucy, R; Aarta, G and Preston, T.R (1988). Molasses - urea blocks as multinutrient supplement for ruminants. In: Sugarcane as Feed. Proceedings of an FAO Experts Consultation held in Santo Domingo. Dominican Republic $7-11$ July 1986. FAO Animal Production and Health paper No 72. 319pp

SAS (1988). Statistical Analysis Systems Institute SAS/STAT Users' Guide: Statistics, version $6.4^{\text {th }}$ Edition. Carey, North Carolina, USA. 943 pp. 